\title{
An Empirical Study on the Relationship between Energy Consumption and Industry Development Chinese
}

\author{
Peng Chen, Xiaoqing Ma, Ling Liu \\ Shanghai University of Electric Power, China, shanghai
}

\begin{abstract}
China's energy consumption and the industrial added value of the data as the foundation, uses econometrics of unit root test, cointegration test and error correction model based the Granger causality test of empirical analysis was carried out on the relationship between its growth. KEYWORD: Energy consumption; Industry development; Cointegration; usal relationship; Error correction model
\end{abstract}

\section{GENERAL INSTRUCTIONS}

What is the relationship between Energy consumption and the added value of Each industry? Whether can adjust and optimize industrial structure to achieve the purpose of reducing energy consumption, Energy consumption and the added value of Each industry to coordinate the harmonious development, is the worth considering and research problems of our government when they draw up the energy strategy and energy policy. Therefore, there is important practical significance to study the Cointegration and causality between them. Our country is in the industry a period of rapid development, with the industrial economy growth and GDP growth, the annual total energy consumption is also growing at a rate of more than $7 \%$, between the growth trend. This phenomenon shows that economic growth and the increase of energy consumption may have a certain influence on the relationship between both. If their one-way or two-way causality between cause and effect, shows that in recent years, our country's economic growth is largely at the expense of energy consumption to drive, the implementation of energysaving policies will affect economic growth; On the contrary, if there is a one-way causal relationship, energy policy will not only reduce the energy consumption, but also does not affect economic growth.

In this paper, based on the data from 1978-2012, first of all to stationarity test of relevant variables, Judgment variables can be further inspection, then using cointegration test and Granger causality analysis method based on error correction model to analyze the long-term equilibrium relationship and short-term fluctuation between Energy consumption and the added value of Each industry, for provide scientific basis for the establishment of China's energy strategy and policy.

\section{DATA SOURCES AND PRETREATMENT}

This paper selects the time series data of the added value of Each industry (GDP1, GDP2, GDP3) and the total energy consumption (Energy Consumption, EC) for the period 1978-2012 in China, sample observation value each is 35 , the original data from the China Statistical Press "China Statistical Yearbook" 2013 edition, "China Energy Statistics Yearbook" 2013 version. Why not select the data before 1978, because "China Energy Statistics Yearbook" in 1978 years ago has not statistical energy consumption, and this part of the data cannot be collected. The added value of the industry is based on the GDP index in 1978 and 1978 of each industry to increase the value of data access, the industry increase in value obtained data are in constant 1978 the industry price real added value, the unit is billion yuan, the energy consumption of the unit is a million tons of standard coal.

\section{EMPIRICAL RESEARCH AND THEORETICAL EXPLANATION}

The following plans to use the econometric model to do in-depth research on the relationship between energy consumption and economic growth in every industry. To eliminate heteroscedasticity and make smooth sequence easier, this article take natural 
logarithm of time series variables, to remember the added value of Each industry respectively after the logarithmic $\quad\{$ LNGDP1,$\quad\{$ LNGDP2 $\}$ and $\{$ LNGDP3 $\}$, to remember the total energy consumption after the logarithmic $\{$ LNEC $\}$.Analysis of all the data in this thesis were completed using the software Eviews6.0.

\subsection{Unit root test}

Table 1 gives the variable level and first difference of ADF, PP, KPSS unit root test results. As shown in Table 1: all the levels of the variables values are I(1), which are nonstationary, and their first order differential sequence is stationary. Visible, the variables are integrated of order one.

\subsection{Cointegration test}

By the unit root test, time series of variables are first difference stationary, then using Engle-Granger two step test of Cointegration Analysis on $\{$ LNEC $\}$ and $\{$ LNGDP1 $\},\{$ LNEC $\}$ and $\{$ LNGDP 2$\},\{$ LNEC $\}$ and \{LNGDP3\}.Using the method of OLS regression equation is obtained as shown in table 2 , the residual unit root test, test results as shown in table 3 .

The cointegration regression equation can be seen, there is positive correlation between energy consumption and three industrial added value, as can be seen, significant relationship from the $\mathrm{T}$ values, and the goodness of fit in more than $90 \%$.

But in the residual sequence of ADF unit root test results, there is a long-term stable equilibrium relationship between energy consumption and the added value of primary industry, the first industrial added value increased by $1 \%$, energy consumption is increased by $0.757759 \%$; there are also the longterm stable equilibrium relationship between energy consumption and the added value of the third industry, third industrial added value increased by $1 \%$, energy consumption is increased by $0.731476 \%$; but does not exist between energy consumption and the added value of the second industry long-term cointegration relationship.

\subsection{Causality test based on error correction model}

On the basis of the test cointegration relationship, can further build will be linked to short-term volatility and long-term equilibrium of vector error correction model. According to the Granger theorem, a group of cointegrated variables has the expression form of error correction model, error correction model is not dependent on some explanatory variables, but only rely on the explanatory variables and the deviation of the longrun relationship among the variables and the dependent variable adjustment, can explain the change process of long-term stable equilibrium relationship between different variable in the economy and their own. Because there are cointegration relationship between energy consumption and the added value of primary industry and third industry, the use of error correction model analysis, the results as shown in table 4:

\section{THE MAIN CONCLUSION AND POLICY RECOMMENDATIONS}

\subsection{The main conclusion}

Based on the above empirical results, we can draw the following conclusion:

4.1.1 The results from the cointegration test, in the long term energy consumption changes will cause the added value of the first industry and the third industry increase worth changes, they have a longterm Granger causality, however, there is no longterm Granger causality between energy consumption and the added value of the second industry. This is a very shocking the empirical results, we usually think that the second industry energy consumption amount, the fastest growing, most should be stronger and the correlation of energy consumption. The reason of this result may be very complex, hand may be energy-saving emission reduction implementation of the second industry has significant effect, on the other hand, the second industrial added value fluctuations, the short term may be associated with energy consumption, but, long-term may not exist significant cointegration relation. And the first and the third industry, although the growth rate is lower than the second industry, but also to keep the fast pace of development, and by the macroeconomic impact relatively less, and instead there is an obvious co-integration relationship between energy consumption.

4.1.2 Based on the error correction model of causality test, in the short- term energy consumption is not $t$ he added value of the first industry and the third industry Granger causes; But in the short term, the added value of primary industry and tertiary industry is the Granger causality of energy consumption.

\subsection{Policy recommendations}

4.2.1 Based on the first conclusion, the government in formulating the energy strategy and energy policy, not only pay attention to the second industry, the same attention to the first industry and the tertiary industry of energy consumption and energy conservation and emissions reduction. Should give priority to the development of energy saving, high 
efficiency of the first, the third industry.

4.2.2 Based on the second conclusion, energy consumption in the short term will not pull the first and the third industry growth, however, the development of the two industries will cause the increase of energy consumption. Therefore, by adjusting and optimizing industrial structure to achieve the purpose of reducing energy consumption, to coordinate the harmonious development of energy consumption and economic growth. Otherwise, is likely to appear in the process of industry adjustment energy constraint bottlenecks or cannot be solved.

\section{ACKNOWLEDGEMENTS}

This research work is supported by Foundation of Shanghai Board of Education Project 2011 (No.12ZS162). The authors gratefully acknowledge their support.

\section{REFERENCES}

[1] Boqiang Lin. Electricity consumption and economic growth of China based on the study of the production function. Management world, 2003, (11).

[2] Zhiyong Han, Yi-ming Wei, etc. China's energy consumption and economic growth of cointegration and causality analysis. Journal of systems engineering, 2004, (12).

[3] Xinxin Zhang, Guangbin Liu. etc. Based on the Granger test of China's energy consumption and economic growth relations research. Journal of shanxi university of finance and economics, 2011, (4).

[4] Hai-ying liu, Ying Zhao. An empirical analysis of the relationship between energy consumption and economic growth of China. Journal of economic aspect, 2011 (03).

[5] Xiaoqi Tang, Lian Xie. China's industrial energy consumption and economic growth of cointegration and causality analysis. Journal of statistical observation, 2009, (14).

[6] Xingzhen Ben, Baochen Yang. China's energy consumption and economic growth of cointegration relationship analysis. Journal of Harbin University of science and technology, 2005, (8).

[7] National Bureau of statistics. Chinese statistical yearbook. Beijing: China Statistics Press, 2013

[8] National Bureau of statistics. China energy statistical yearbook. Beijing: Chinese Statistics Press, 2013

[9] Danhui Yi. Data analysis and application of EVIEWS. Beijing: Renmin University of China press, 2009.8.

[10] Zinai Li. Econometrics. Beijing: Higher Education Press, 2006, 2

[11] Tiemei Gao. Econometric analysis method and modeling. Beijing: tsinghua university press, 2005.10

\section{APPENDIX}

Table 1: the variable unit root test results

\begin{tabular}{|c|c|c|c|c|c|}
\hline variable & Test type $(\mathrm{C}, \mathrm{T}, \mathrm{K})$ & ADF test & PP test & KPSS test & conclusion \\
\hline LnEC & $\mathrm{C}, \mathrm{T}, 3$ & -2.778176 & -2.887097 & 0.525076 & Not smooth \\
\hline LnGDP1 & $\mathrm{C}, \mathrm{T}, 1$ & -2.291729 & -2.479036 & 0.649412 & Not smooth \\
\hline LnGDP2 & $\mathrm{C}, \mathrm{T}, 3$ & -2.326519 & -2.751509 & 0.428191 & Not smooth \\
\hline LnGDP3 & $\mathrm{C}, \mathrm{T}, 3$ & -2.049582 & -2.840856 & 0.597232 & Not smooth \\
\hline$\triangle$ LnEC & $\mathrm{C}, 0,3$ & $-2.943415^{*}$ & $-3.146939 * *$ & $0.447017 * *$ & smooth \\
\hline$\triangle$ LnGDP1 & $\mathrm{C}, 0,2$ & $-3.652787^{* * *}$ & $-3.652787^{* * *}$ & $0.194431^{*}$ & smooth \\
\hline$\triangle$ LnGDP2 & $\mathrm{C}, 0,2$ & $-2.932725^{*}$ & $-2.932725^{*}$ & $0.251206^{*}$ & smooth \\
\hline$\triangle$ LnGDP3 & $\mathrm{C}, 0,3$ & $-3.881582^{* * *}$ & $-3.881582^{* * *}$ & $0.406195^{* *}$ & smooth \\
\hline
\end{tabular}

Note: data in this table is in the unit root test are based on the OLS estimation, test type of C, T, K, paragraphs respectively with a constant and trend, lag order number, lag of step length selection of $\mathrm{K}$ value be determined by the Schwarz information criterion (SIC). The null hypothesis H0 sequence of ADF test and PP test is I (1), the alternative hypothesis of H1 sequence is I (0), while the null hypothesis H0 sequence of the KPSS test is I (0), the alternative hypothesis of $\mathrm{H} 1$ sequence is I (1).*** denotes significant at $1 \%$ level, ** significant at the $5 \%$ level, * indicates significant at $10 \%$ level.

Table 2: Cointegration regression equation test results

\begin{tabular}{|c|c|c|c|}
\hline variable & Regression equation & Adjusted $\mathrm{R}^{2}$ & DW \\
\hline LNEC and LNGDP1 & $\begin{array}{c}\mathrm{LNEC}=5.554470+0.757759 * \mathrm{LNGDP}^{2}+\mathrm{E}_{\mathrm{t} 1} \\
\mathrm{~T} \text { value } \quad(18.56542)\end{array}$ & 0.929632 & 0.133302 \\
\hline LNEC and LNGDP2 & $\begin{array}{c}\mathrm{LNEC}=1.778205+1.234312 * \mathrm{LNGDP} 2+\mathrm{E}_{\mathrm{t} 2} \\
\mathrm{~T} \text { value } \quad(3.378258)\end{array}$ & 0.916444 & 0.110043 \\
\hline LNEC and LNGDP3 & $\begin{array}{c}\mathrm{LNEC}=6.063954+0.731476 * \mathrm{LNGDP} 3+\mathrm{E}_{\mathrm{t} 3} \\
\mathrm{~T} \text { value } \quad(19.91955)\end{array}$ & 0.915039 & 0.090222 \\
\hline
\end{tabular}


Table 3: the residual error of ADF unit root test results

\begin{tabular}{|c|c|c|c|c|c|}
\hline variable & Statistical quantity & $1 \%$ level of significance & $5 \%$ level of significance & $10 \%$ level of significance & Conclusion \\
\hline $\mathrm{E}_{\mathrm{t} 1}$ & $-2.784489 * * *$ & -2.650145 & -1.953381 & -1.609798 & smooth \\
\hline $\mathrm{E}_{\mathrm{t} 2}$ & -1.345876 & -2.636901 & -1.951332 & -1.610747 & Not smooth \\
\hline $\mathrm{E}_{\mathrm{t} 3}$ & $-2.442937 * *$ & -2.641672 & -1.952066 & -1.610400 & smooth \\
\hline
\end{tabular}

Table 4: LNEC and LNGDP1/ LNGDP3 Granger causality test

\begin{tabular}{|c|c|c|c|}
\hline \multirow{2}{*}{ The dependent variable } & \multicolumn{3}{|c|}{ The independent variables } \\
\hline & \multicolumn{2}{|c|}{ Short-term } & Long-term (ECT) \\
\hline $\mathrm{D}(\mathrm{LNEC})$ & $\mathrm{D}(\mathrm{LNGDP} 1(-1))$ & $-1.898346 *(0.0676)$ & $-0.040243(0.9682)$ \\
\hline D(LNGDP1) & $\mathrm{D}(\mathrm{LNEC}(-1))$ & $1.289105(0.2925)$ & $1.798619 *(0.0829)$ \\
\hline $\mathrm{D}(\mathrm{LNEC})$ & D(LNGDP3(-1)) & $-1.866027 *(0.0722)$ & $-0.123710(0.9024)$ \\
\hline D(LNGDP3) & $\mathrm{D}(\mathrm{LNEC}(-1))$ & $0.454969(0.7163)$ & $1.743320 *(0.0946)$ \\
\hline
\end{tabular}

The table reports is t- statistics, () for P value. 